\title{
HUBUNGAN TINGKAT PENGETAHUAN IBU TENTANG GIZI BALITA DENGAN STATUS GIZI BALITA DI WILAYAH KERJA PUSKESMAS GAJAH 1 DEMAK
}

\author{
Endang Susilowati ${ }^{1)}$, Alin Himawati2) \\ esusilowati27@gmail.com
}

\begin{abstract}
Nutritional status is one indicator of health is considered successful achievements in MDGs (Millennium Development Goals). Nutritional status is important because one of the risk factors for morbidity and mortality. Nutritional status is good for one will contribute to health. Knowledge of nutrition toddler is a factor that can affect the nutritional status of children because mother with good knowledge will apply knowledge of nutritional behavior through the provision of nutritious food for toddlers. The purpose of this study was to determine the relationship between the mother's level of knowledge about nutrition with nutritional status of children under five in the area of Occupational Health Center Gajah 1 Demak.

Type of observational analytic survey research with cross-sectional time approaches, the number of samples of 95 respondents with sampling stratified random sampling technique. Test the relationship between variables using Chi-Square.

The results showed that the majority Good level of knowledge of the majority of respondents were 53 respondents $(55 \%)$ have nourished toddlers that is $81.13 \%$ more than those with less knowledge is $54.76 \%$. The majority of children under five suffering malnutrition and poor have bad knowledgeable mothers were 19 respondents (45.23\%). Of statistical test $\mathrm{P}=0.006$, which means at $\mathrm{p}<0.05$.

Conclusion, there is a meaningful relationship between the level of knowledge mother toddler nutrition toddler. Advice for moms toddlers to increase knowledge about nutrition toddler.
\end{abstract}

Keywords: knowledge, nutritional, nutritional status of children

1), 2), Dosen Prodi D3 Kebidanan Fakultas Kedokteran Unissula Semarang

Menurut Badan Penelitiandan Pengembangan Kesehatan dalam Riset Kesehatan Dasar 2010 tercatat jumlah balita di Indonesia sebanyak 26,7 juta. Dari jumlah tersebut $17,9 \%$ atau 4,7 juta balita menderita gizi kurang dan $5,4 \%$ atau 1,3 juta balita menderita gizi buruk. Status gizi balita adalah salah satu indikator kesehatan yang dinilai keberhasilan pencapaiannya dalam MDGs (Millenium Development Goals). Status gizi ini menjadi penting karena salah satu faktor risiko untuk terjadinya kesakitan dan kematian. Status gizi yang baik bagi seseorang akan berkontribusi terhadap kesehatannya dan juga terhadap kemampuan dalam proses pemulihan(Profil Kesehatan 
Jawa Tengah tahun 2011). Gizi kurang berdampak langsung terhadap kesakitan dan kematian. Disamping itu gizi kurang juga berdampak terhadap pertumbuhan, perkembangan intelektual dan produktivitas. Anak yang kekurangan gizi pada usia balita akan tumbuh pendek, dan mengalami gangguan pertumbuhan dan perkembangan otak yang berpengaruh pada rendahnya tingkat kecerdasan, karena tumbuh kembang otak $80 \%$ terjadi pada masa dalam kandungan sampai usia 2 tahun. Dampak lain dari gizi kurang adalah menurunkan produktivitas yang diperkirakan antara 20-30\% (Hernawati, 2011; h.5).

Diantara 35 Kabupaten yang ada di provinsi Jawa Tengah, Kabupaten Demak menduduki peringkat ke-5 dengan masalah gizi balita tertinggi. Empat Kabupaten yang lainnya yaitu Kabupaten Pemalang, Grobogan, Tegal dan Jepara. Tahun 2011 di Kabupaten Demak terdapat kasus gizi buruk sebesar 1,54\% dan gizi kurang sebesar $11,53 \%$, sedangkan tahun 2012 terdapat kasus gizi buruk sebesar $1,17 \%$ dan gizi kurang sebesar 12,09\%. Hal ini menunjukkan bahwa Kabupaten Demak merupakan daerah rawan gizi dengan interpretasi bahwa kondisi balita dengan gizi buruk > $0,05 \%$. Hal ini mungkin disebabkan karena asupan gizi kurang, \& penyakit infeksi, pola asuh tidak baik, kemiskinan, kurang pengetahuan dan lain lain.

Status gizi adalah ekspresi dari keadaan keseimbangan dalam bentuk variabel tertentu atau perwujudan dari nutriture dalam bentuk variabel tertentu (Supariasa, 2012). Penilaian status gizi dapat dibagi menjadi empat penilaian yaitu ; antropometri, klinis, biokimia dan biofisik. Berdasarkan buku Harvard status gizi dapat dibagi menjadi empat yaitu : 1) Gizi lebih untuk over weight, termasuk kegemukan dan obesitas, 2) Gizi baik untuk well nourished,3) Gizi kurang untuk under weight yang mencakup mild dan moderate PCM (Protein Calorie Malnutrition), 4) Gizi buruk untuk severe $P C M$, termasuk marasmus, marasmikkwasiorkor dan kwashiorkor.

Masa balita adalah masa partumbuhan sehingga memerlukan gizi yang baik. Kebutuhan zat-zat gizi utama yang meliputi 5 komponen dasar, yakni hidrat arang, protein, lemak, mineral dan vitamin (termasuk air dalam yang cukup). Kebutuhan gizi pada balita diantaranya energi, protein, lemak, air, hidrat arang dan vitamin mineral. Merryana (2012). Tujuan dari pene-litian ini adalah untuk mengetahui hubungan tingkat penge-tahuan ibu tentang gizi balita dengan status gizi balita di wilayah kerja Puskesmas Gajah 1 Demak.

\section{METODE}

Ruang lingkup dalam penelitian ini adalah kesehatan anak khususnya ten-tang gizi anak, jenis penelitian survey observasional analitik dengan rancangan penelitian yang digunakan adalah survei cross sectional. Untuk mengetahui tingkat pengetahuan Instrumen yang digunakan adalah kuesioner sedangkan untuk mengetahui status gizi alat yang digunakan adalah timbangan, penelitian dilaksanakan di wilayah kerja Pus-kesmas Gajah 1 Kabupaten Demak. Sumber data yang digunakan adalah data primer: data yang diperoleh dengan cara memberikan kuesioner pada responden untuk mengetahui tingkat pengetahuan ibu dan pemerik-saan langsung dengan cara melakukan pe-nimbangan berat 
badan anak. Sedangkan data sekundernya adalah data diperoleh dari data PSG (Pemantauan Status Gizi) balita.

Teknik analisis data mencakup analisis univariate dan analisis bivariate. Analisa univariat dalam penelitian ini menggunakan program sistem komputerisasi, dengan menggunakan statistik sederhana yaitu prosentase dan distribusi frekuensi.

Sedangkan analisis bivariate data yang didapat dianalisa dengan menggunakan uji statistik Chi-Square $\left(\mathrm{x}^{2}\right)$. Namun syarat uji Chi-Square tidak memenuhi karena sel yang nilai ekspektasinya $<5$ lebih dari $20 \%$ yaitu $50,0 \%$ sehingga dilakukan penggabungan sel untuk dilakukan uji Chi-Square kembali.

\section{HASIL DAN PEMBAHASAN}

Diagram. 1.

Tingkat Pengetahuan Ibu

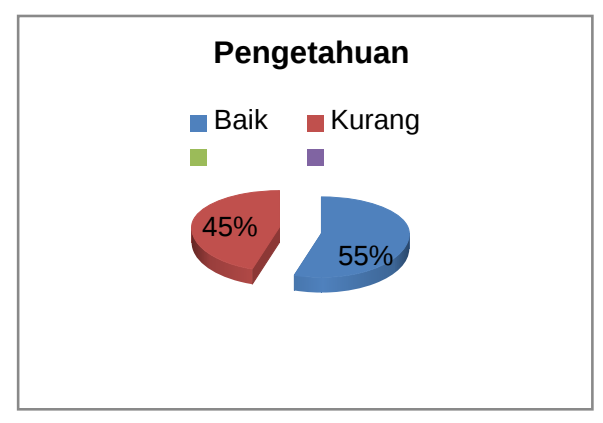

Grafik 1.

Status GiziBalita

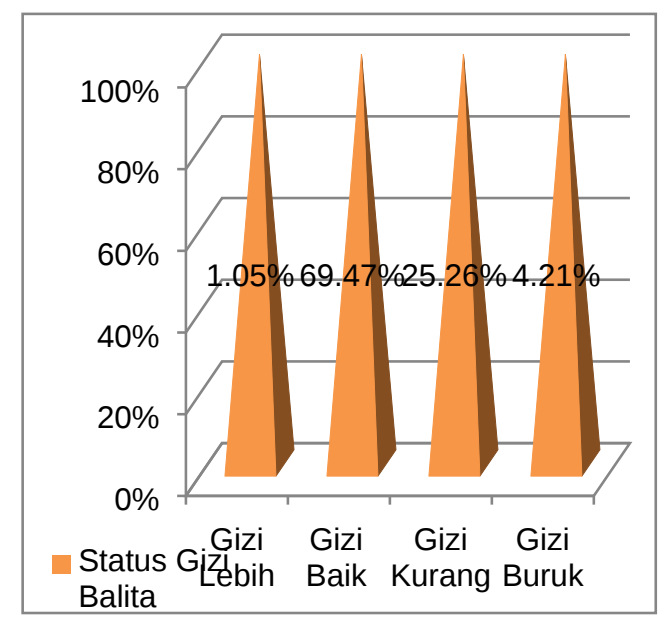

Berdasarkan Grafik 1 dapat diketahui bahwa status gizi balita mayoritas mempunyai status gizi yang baik yaitu $69,47 \%$, sedangkan gizi kurang menempati urutan kedua yaitu $25,26 \%$.

Tabel 1.Tabel Silang Penggabungan Sel Tingkat Pengetahuandengan Status Gizi di Wilayah Puskesmas Gajah 1 Demak

Berdasarkan diagram 1 dapat diketahui bahwa mayoritas pengetahuan ibu tentang gizi balita baik yaitu sebesar $55 \%$ sedangkan $45 \%$ mempunyai pengetahuan yang kurang.

\begin{tabular}{|c|c|c|c|c|c|c|c|}
\hline \multirow{2}{*}{$\begin{array}{c}\text { Pengeta } \\
\text { huan }\end{array}$} & \multicolumn{4}{|c|}{ Status Gizi Balita } & \multirow{2}{*}{$\begin{array}{c}\text { juml } \\
\text { ah }\end{array}$} & \multirow{2}{*}{$\mathbf{X}^{2}$} & \multirow{2}{*}{$\begin{array}{c}\rho \\
\text { value }\end{array}$} \\
\hline & $\begin{array}{c}\text { kura } \\
\text { ng }\end{array}$ & $\%$ & $\begin{array}{c}\text { Bai } \\
\mathbf{k}\end{array}$ & $\%$ & & & \\
\hline Kurang & 19 & 45,23 & 23 & 54,76 & 42 & \multirow{2}{*}{7,692} & \multirow{2}{*}{0,006} \\
\hline Baik & 9 & 16,98 & 44 & 83,01 & 53 & & \\
\hline Jumlah & 28 & 29,47 & 67 & $\mathbf{7 0 , 5}$ & 95 & & \\
\hline
\end{tabular}


Berdasarkan Tabel diatas dapat diketahui bahwa ibu dengan pengetahuan baik mayoritas memiliki balita dengan status gizi baik yaitu $83,01 \%$ lebih banyak dibandingkan dengan ibu berpengetahuan kurangyaitu 54,76\%.

Hasil analisis dengan chi square diperoleh hasil signifikansi $p$ value $=$ 0,006 , karena $p$ value $<0,05$ maka secara statistik ada hubungan yang signifikan antara tingkat pengetahuan ibu tentang gizi balita dengan status gizi balita.

Berdasarkan penelitian didapatkan 53 responden (55\%) memiliki tingkat pengetahuan baik. Hal tersebut menunjukkan bahwa mayoritas responden memiliki pengetahuan yang baik tentang kebutuhan gizi balita. Berdasarkan kenyataan di lapangan, ibu dengan pengetahuan baik mengenai kebutuhan gizi balita cenderung memiliki anak yang berstatus gizi baik pula. Hal ini berkaitan dengan pemahaman ibu tentang manfaat dan fungsi makanan bergizi bagi pertumbuhan dan perkembangan balitanya. Pengetahuan yang didasari dengan pemahaman yang tepat akan menumbuhkan perilaku baru yang diharapkan. Berdasarkan hasil penelitian dapat dijelaskan bahwa sebagian besar responden mempunyai balita dengan gizi baik yaitu sebanyak 66 orang $(69,47 \%)$, gizi kurang sebanyak 24 responden $(25,26 \%)$, gizi buruk sebanyak 4 responden $(4,21 \%)$ sedangkan responden yang mempunyai balita dengan gizi lebih hanya 1 orang $(1,05 \%)$.

Menurut Supariasa (2012; h.18), status gizi adalah ekspresi dari keadaan keseimbangan dalam bentuk variabel tertentu atau perwujudan dari nutriture dalam bentuk variabel tertentu. Status gizi balita sangat dipengaruhi oleh tingkat pengetahuan seorang ibu karena ibu memiliki keterikatan yang lebih dengan anaknya. Ia lebih sering bersama dengan anaknya dibandingkan dengan anggota keluarga sehingga ibu tahu persis kebutuhan gizi balita. Ibu dengan tingkat pengetahuan yang baik akan menghasilkan anak berstatus gizi baik juga karena pemahaman dan pengetahuan ibu telahd iaplikasikan dalam perilaku pemberian makanan bergizi bagi balita.

Faktor yang dapat mempengaruhi status gizi pada balita adalah asupan makanan pada anak dan penyakit infeksi yang merupakan penyebab langsung, sedangkan penyebab tidak langsungnya adalah persediaan makanan dirumah, pengetahuan, pola pengasuhan anak, pelayanan kesehatan dan kesehatan lingkungan serta kemiskinan. Pengetahuan dalam penelitian ini adalah pemahaman ibu balita tentang kebutuhan gizi balita meliputi pengertian zat gizi, macam-macam, manfaat dan tanda kekurangan gizi. Secara proporsi menunjukkan ibu berpengetahuan baik mayoritas memiliki balita dengan gizi baik yaitu $83,01 \%$ lebih banyak dibandingkan ibu dengan pengetahuan kurang yaitu $54,76 \%$.

Tingkat pengetahuan ibu tentang gizi balita sangat mempengaruhi keadaan gizi balita tersebut karena ibu adalah seorang yang paling besar keterikatannya terhadap anak. Kebersamaan ibu dengan anaknya lebih besar dibandingkan dengan anggota keluarga yang lain sehingga lebih mengerti segala kebutuhan yang dibutuhkan anak. Pengetahuan yang dimiliki ibu menjadi kunci utama kebutuhan gizi balita terpenuhi. Pengetahuan yang didasari dengan pemahaman yang baik dapat menumbuhkan perilaku baru yang baik pula. Pengetahuan ibu tentang kebutuhan gizi yang dipahami 
dengan baik akan diiringi dengan perilaku pemberian makanan bergizi bagi balita. Pengetahuan bisa didapat dari informasi berbagai media seperti $\mathrm{TV}$, radio atau surat kabar seperti halnya dalam penelitian ini. ibu mendapatkan informasi tentang kebutuhan gizi balita dari penyuluhan yang diberikan puskesmas setiap pelaksanaan program posyandu .Informasi ini meningkatkan pengetahuan yang diiringi dengan perilaku baru dalam pemberian makanan bergizi bagi balita sehingga status gizi pun menjadi baik.

Pendapat ini didukung oleh teori menurut Simanulang (2010) bahwa informasi juga akan memberikan pengaruh pada pengetahuan seseorang. Meskipun seseorang memiliki penddikan rendah tetapi jika ia mendapatkan info yang baik dari berbagai media seperti $\mathrm{TV}$, radio atau surat kabar makalah itu akan dapat meningkatkan pengetahuan seseorang.

\section{SIMPULAN}

Berdasarkan hasil penelitian dan pembahasan dapat ditarik kesimpulan : mayoritas responden mempunyai pengetahuan yang baik tentang gizi Balita, Status gizi Balita di Wilayah Kerja Puskesmas Gajah 1 mayoritas berstatus Gizi baik. Hasil analisis dengan chi square diperoleh hasil signifikansi $p$ value $=0,006$, karena $p$ value $<0,05$ maka secara statistik ada hubungan yang signifikan antara tingkat pengetahuan ibu tentang gizi balita dengan status gizi balita.

\section{DAFTAR PUSTAKA}

Departemen Gizi dan Kesehatan Masyarakat UI. 2011. Gizi dan
Kesehatan Masyarakat. Jakarta : PT. Rajagrafindo Persada.

Hernawati, I. Pencegahan Dan Penanggulangan Gizi Buruk dalam Seminar Nasional Hari Pangan Sedunia XXVII Du-kungan Teknologi Untuk Meningkatkan Produk Pangan Hewani Dalam Rangka Pemenuhan Gizi Masyarakat. 7 April 2013

Irianto, Waluyo. 2007. Gizi dan Pola Hidup Sehat. Bandung: Yrama Widya.

Istiany A, Rusilanti. 2013. Gizi Terapan. Bandung: PT. Remaja Rosdakarya.

Marimbi H. 2010. Tumbuh Kembang, Status Gizi dan Imunisasi Dasar Pada Balita.Yogyakarta: Nuha Medika.

Merryana A. 2012. Peran Gizi dalam Siklus Kehidupan. Jakarta: Kharisma Putra Utama.

Proverawati, Kusumawati. 2010. Ilmu Gizi Untuk Keperawatan dan Gizi Kesehatan. Yogyakarta: Nuha Medika.

Riyanto A. 2009. Pengolahan dan Analisis Data Kesehatan. Yogyakarta: Nuha Medika.

Santoso S, Rianti. 2009. Kesehatan dan Gizi. Jakarta: Rineka Cipta.

Simanullang, Sari dewi. 2010. Hubungan antara tingkat Pengetahuan Suami tentang Perawatan Kehamilan Diklinik Bersalin Mariani Medan. 30 September 2011.

Supariasa, dkk. 2012. Penilaian Status Gizi. Jakarta: EGC. 